\title{
PENGEMBANGAN SUMBER DAYA MANUSIA BERBASIS TOTAL QUALITY MANAGEMENT DI SMK MUHAMMADIYAH PRAMBANAN
}

\author{
Erlina Yuliyati ${ }^{1}$ \\ ${ }^{1}$ Universitas Islam Negeri Sunan Kalijaga, Yogyakarta, Indonesia \\ Email : yuliyatierlina@gmail.com ${ }^{1}$
}

DOI: http://doi.org/10.33650/al-tanzim.v4i1.967

\begin{tabular}{l|l|l} 
Received: Januari 2020 & Accepted: Maret 2020 & Published: Maret 2020
\end{tabular}

\begin{abstract}
:
This paper presents the development of human resources based on total quality management conducted at SMK Muhammadiyah Prambanan. Total quality management is an approach offered, so that educational institutions can survive and be able to win the competition between existing institutions. This research uses a qualitative approach with case study. The technique of collecting data is done through; observation, interview and documentation. Research data are presented in narrative descriptive form. The results showed that; SMK Muhammadiyah Prambanan implements several stages in human resource management, namely; planning, recruitment, and development of human resources that are carried out in a planned, systematic and oriented towards continuous quality improvement. Through the implementation of total quality management, "SMK Muhammadiyah Prambanan" managed to become a superior school and gain the trust of the public.
\end{abstract}

Key words : Human resources, total quality management, competitive

\begin{abstract}
Abstrak :
Paper ini menyajikan tentang pengembangan sumber daya manusia berbasis total quality management yang dilakukan di SMK Muhammadiyah Prambanan. Total quality management merupakan pendekatan yang ditawarkan agar supaya lembaga survive dan mampu memenangkan persaingan antar lembaga yang ada. Penelitian ini menggunakan pendekatan kualitatif jenis studi kasus. Teknik pengumpulan datanya dilakukan melalui; observasi, wawancara dan dokumentasi. Selanjutnya data hasil penelitian disajikan dalam bentuk deskriptif naratif. Hasil penelitian menunjukkan bahwa; SMK Muhammadiyah Prambanan menerapkan beberapa tahapan dalam manajemen sumber daya manusia, yaitu perencanaan, perekrutan, dan pengembangan sumber daya manusia yang dilakukan secara terencana, sistematis dan berorientasi pada perbaikan mutu secara berkelanjutan. Melalui penerapan total quality management, SMK Muhammadiyah Prambanan berhasil menjadi sekolah yang unggul dan mendapatkan kepercayaan dari public.
\end{abstract}

Kata Kunci : Sumber daya manusia, total quality management, kompetitif 


\section{PENDAHULUAN}

Sumber daya manusia (SDM) merupakan faktor inti dalam suatu organisasi. Oleh sebab itu, pengelolaan dan pengembangan sumber daya manusia menjadi hal yang sangat penting bagi organisasi (Krismiyati, 2017). Manajemen sumber daya manusia dilakukan untuk mengembangkan dan mendayagunakan seluruh potensi yang ada guna mendukung dalam pencapaian tujuan organisasi yang diinginkan.

Pengembangan sumber daya manusia menjadi bagian dari topik yang penting untuk dikaji, mengingat pengembangan sumber daya manusia adalah aspek yang urgen dalam upaya meningkatkan keunggulan bersaing lembaga (Aryana et al., 2017); (Muhardi, 2004). Pengembangan sumber daya manusia merupakan pengembangan tenaga kerja yang berorientasi pada peningkatan ilmu pengetahuan dan keterampilan yang akhir tujuannya adalah produktifitas dan kualitas lemabaga (Widiansyah, 2018).

Lembaga pendidikan memerlukan pengelolaan sumber daya manusia yang efektif dalam meningkatkan kinerjanya. Upaya dalam peningkatan kualitas, berimplikasi pada perlunya sekolah untuk memiliki sumber daya manusia untuk bekerja secara optimal, sehingga berakibat pada perlunya melakukan pengembangan sumber daya manusia agar memiliki sikap kreatif dan inovatif dalam menghadapi persaingan (Walidin, 2016).

Adanya ketidakcocokan antara out put pada jenjang pendidikan dengan tuntutan masyarakat (social demands) dalam dunia kerja, merupakan pekerjaan rumah dalam dunia pendidikan yang harus dibenahi. Pendidikan masih memperlihatkan sebagai suatu beban dibanding kekuatan dalam pembangunan. Jika dilihat dari perspektif human capital theory, pendidikan dihadapkan dengan persoalan under investment in human capital, yaitu kurangnya pengembangan potensi SDM, sehingga berdampak pada pendidikan belum menunjukan rate of return yang dapat diukur dari besarnya lulusan pendidikan yang terserap keduania kerja (Buniarto, 2015).

Salah satu faktor yang berpengaruh terhadap berhasil tidaknya suatu lembaga pendidikan adalah kinerja sumber daya di dalamnya. Sumber daya yang dimiliki sekolah tidak dapat memberikan hasil maksimal, jika tidak didukung oleh SDM yang memiliki kinerja optimal sebagaimana diharapkan. Pekerjaan yang produktif dan berkualitas merupakan perbuatan yang disukai dalam Islam. Banyak ayat Al-Qur'an menyinggung tentang mutu, akan tetapi perlu dipahami secara kontekstual bahwa Islam juga menghendaki agar kita selalu berupaya untuk menjadi lebih baik, sebagaimana dijelaskan dalam surah Ar-Ra'd ayat 11 berikut:

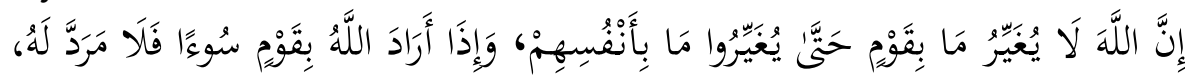

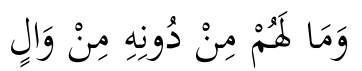

Artinya:

Sesungguhnya Allah tidak merubah keadaan suatu kaum, sehingga mereka merubah keadaannya sendiri. Apabila Allah menghendaki keburukan terhadap sesuatu kaum, Maka tak ada yang dapat menolaknya; dan sekali-kali tak ada pelindung bagi mereka selain Dia. 
Banyak peneliti yang melakukan penelitian tentang pengembangan sumber daya manusia, diantaranya; Priyatna (2016); (Jaya, 2017); (Krismiyati, 2017), yang melakukan penelitian tentang pentingnya pengembangan sumber daya manusia dalam mencapai tujuan organisasi. Kondisi lingkungan yang dinamis, penempatan pegawai, tidak selalu menyebabkan keberhasilan. Kondisi lingkungan lebih cederung menuntut organisasi untuk melakukan penyesuaian dan pengembangan sesuai dengan kebutuhan organisasi. Penelitian lainnya juga dilakukan oleh Warisno (2018) yang menyatakan bahwa mutu dapat tercapai apabila SDM yang dalam hal ini adalah pendidik dan tenaga kependidikan dioptimalkan melalui manajemen yang handal. Salah satu manajemen yang dilakukan adalah dengan "buy" dan "make" (rekrutmen dan pembinaan).

Pengembangan dan peningkatan kualitas sumber daya manusia hendaknya menjadi prioritas. Salah satu upaya yang dapat dilakukan untuk meningkatkan kualitas sumber daya manusia adalah dengan menerapkan prinsip-prinsip Total Quality Management (TQM). Penerapan TQM terhadap peningkatan kualitas sumber daya manusia terbukti memberikan kontribusi besar bagi pencapaian tujuan (Supardi, 2006).

Total quality management adalah sebuah pendekatan dan tawaran konsep sederhana tentang bagaimana lembaga dapat bersaing dan unggul dalam persaingan serta menghasilkan kualitas terbaik diantara lembaga yang ada (Syam, 2017). Untuk dapat menghasilkan kualitas terbaik, maka diperlukan perbaikan secara berkelanjutan dan berkesinambungan terhadap sumber daya manusia (Suhermanto, 2018). Selain itu, konsep total quality management juga memiliki ciri, yaitu berorientasi pada kepuasan kebutuhan pelanggan dan pencapaian jangka panjang (Hijrawan, 2019).

Proses pengembangan sumber daya manusia berbasis total quality management memiliki syarat yang harus dipenuhi, yaitu komitmen penuh seluruh elemen untuk melaksanakan pengukuran sebagai suatu evaluasi. Evaluasi dan perbaikan dilakukan secara berkelanjutan untuk memperbaiki kualitas, yang dimulai dari perencanaan, perekrutan, seleksi, pengembangan, peniaian kinerja sampai dengan pemutusan kontrak kerja (Rachmawati, 2008)

SMK Muhammadiyah Prambanan merupakan sekolah yang tergolong maju dan memiliki keunggulan kompetitif karena mampu membaca dan melihat peluang yang ada. Selain itu, lembaga tersebut selalu melakukan kegiatan pengembangan kualitas sumber daya manusia secara terencana, sistematis dna berkesinambungan. Hasil observasi awal, diperoleh informasi bahwa pihak sekolah selalu melakukan peningkatan kemampuan para pendidik dan tenaga kependidikannya secara terencana yang tertuang dalam Rencana Kerja Sekolah (RKS), serta memberikan reward dan punishment kepada pendidik dan tenaga kependidikannya.

Pengembangan keterampilan serta kemampuan sumber daya manusia yang dimiliki sekolah terus dilakukan dalam rangka menjawab tuntutan masyarakat dan ketatnya persaingan antar lembaga pendidikan. Mengingat sumber daya manusia merupakan faktor produksi yang harus ada dan menjadi komponen penting dalam organisasi, maka aspek ini harus mendapatkan 
perhatian serius dari lembaga, agar supaya tujuan organisasi dapat tercapai dengan optimal (Hartatik, 2014).

SDM yang ada pada lembaga pendidikan, mencakup tenaga pendidik (guru) dan tenaga kependidikan yang meliputi pegawai administrasi, laboran, pustakawan, teknisi, serta pembantu pelaksana (tenaga kebersihan). Manajemen sumber daya manusia dipahami sebagai proses perencanaan, pengorganisasian, pengarahan, dan pengawasan, mulai dari pengadaan, pengembangan, pengkompensasian, sampai pemeliharaan tenaga kerja dengan maksud membantu mencapai tujuan yang telah dirumuskan (Hasan, 2003).

Penelitian tentang sumber daya manusia telah banyak dilakukan, akan tetapi berdiri sendiri. Dalam hal ini, penelitian ini hadir dengan internalisasi konsep total quality management dalam pengelolaan SDM di lembaga pendidikan, khususnya di SMK Muhammadiyah Prambanan, mengingat ada kekhasan dan keunikan yang dimiliki oleh lembaga tersebut dalam mengelola sumber daya manusianya agar berkualitas dan mampu meningkatkan daya saing lembaganya.

\section{METODE PENELITIAN}

Metode yang digunakan dalam penelitian ini adalah penelitian kualitatif jenis studi kasus. Metode penelitian kualitatif merupakan penelitian ilmiah yang bertujuan untuk memahami suatu fenomena sosial dengan mengedepankan proses interaksi dan komunikasi yang mendalam antara peneliti dengan fenomena yang diteliti (Sugiyono, 2017). Dengan demikian, dalam penelitian kualitatif peneliti menjadi sumber instrument yaitu pengumpul data secara langsung. Penelitian ini bersifat deskripsi analisis, yang mana pengumpulan datanya dilakukan melalui; observasi, wawancara serta dokumentasi, kemudian peneliti melakukan analisis sampai penelitian dinyatakan selesai.

\section{HASIL DAN PEMBAHASAN}

SMK Muhammadiyah Prambanan didirikan pada tahun 1967, yang terletak di sebelah selatan panggung Sendratari Ramayana. Pada awalnya sekolah tersebut kurang diminati oleh masyarakat, karena pada masa itu, SMK masih terasa asing di mata masyarakat sekitar. Namun, seluruh pengurus tetap berusaha keras dan bertekad untuk memajukan SMK Muhammadiyah Prambanan agar mampu bersaing dengan lembaga pendidikan di sekitarnya.

Berkat usaha yang gigih dan serius dari para pengelolanya, dengan mengintegrasikan total quality managemenent dalam setiap aktivitas organisasinya, SMK Muhammadiyah Prambanan mengalami perkembangan yang sangat pesat dan mampu bersaing dengan lembaga pendidikan yang ada di sekitarnya. Hal tersebut terbukti dari peningatan jumlah siswa tiap tahunnya, di samping prestasi yang dicapai oleh sekolah. Perkembangan jumlah siswa SMK Muhammadiyah Prambanan dapat dilihat sebagaimana diagram berikut: 


\section{Perkembangan siswa SMK Muhammadiyah Prambanan}

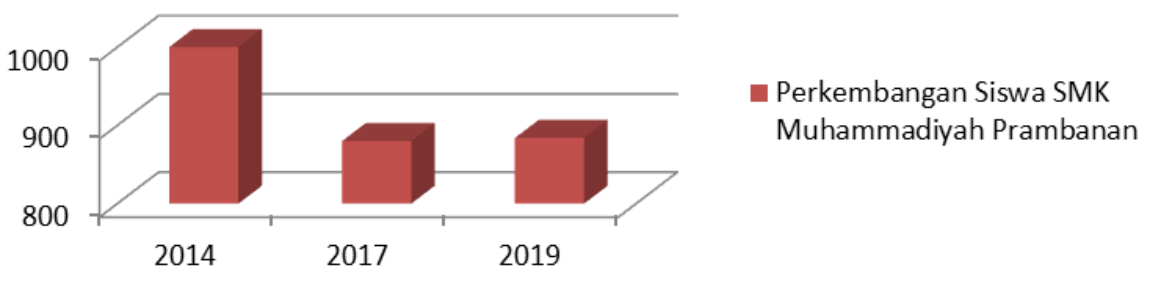

Gambar 1 : Perkembangan jumlah siswa SMK Muhammadiyah Prambanan

Berdasarkan gambar 1 tersebut, dapat diketahui bahwa peningkatan jumlah siswa di SMK Muhammadiyah Prambanan mengalami naik-turun (fluktuasi). Namun demikian, Devisi Penjamin Mutu SMK Prambanan, Hartati (2019) mengungkapkan bahwa; sekolah tersebut menjadi sekolah peringkat pertama tingkat SMK di Kabupaten Sleman, Yogyakarta. Hal ini tidak lepas dari peran pengelola lembaga, guru dan tenaga pendidikan yang profesional dan turut aktif dalam mamajukan SMK Muhammadiyah Prambanan. Adapun data guru dan kependidikan di SMK Muhammadiyah Prambanan sebagai berikut:

Tabel 1 : Data Guru dan Tenaga Kependidikan

\begin{tabular}{crcc}
\hline No & Uraian & Guru & Tendik \\
\hline $\mathbf{1}$ & Laki - Laki & 49 & 13 \\
\hline $\mathbf{2}$ & Perempuan & 21 & 5 \\
\hline & TOTAL & $\mathbf{7 0}$ & $\mathbf{1 8}$ \\
\hline
\end{tabular}

Tabel 1 tersebut menunjukkan bahwa SMK Muhammadiyah Prambanan berusaha untuk menyesuaikan rasio antara guru, tenaga kependidikan dengan jumlah peserta didik. Peningkatan mutu dilakukan melalui manajemen yang tepat guna, yaitu total quality management atau manajemen mutu terpadu dalam setiap aktivitas dan kegiatan organisasi, terutama dalam pengelolaan dan pengembangan kualitas sumber daya manusia di dalamnya.

Hal ini dapat diketahui dari hasil temuan penelitian di lapangan bahwa; untuk meningkatkan mutu pendidikan, agar memiliki daya saing dan unggul, maka penguatan dan pengembangan kualitas sumber daya manusia di SMK Muhammadiyah Prambanan mutlak dilakukan. Oleh karenanya, SMK Muhammadiyah Prambanan menggunakan pendekatan total quality management dalam mengembangkan kualitas sumber daya manusianya. Hal tersebut dapat digambarkan sebagai berikut;
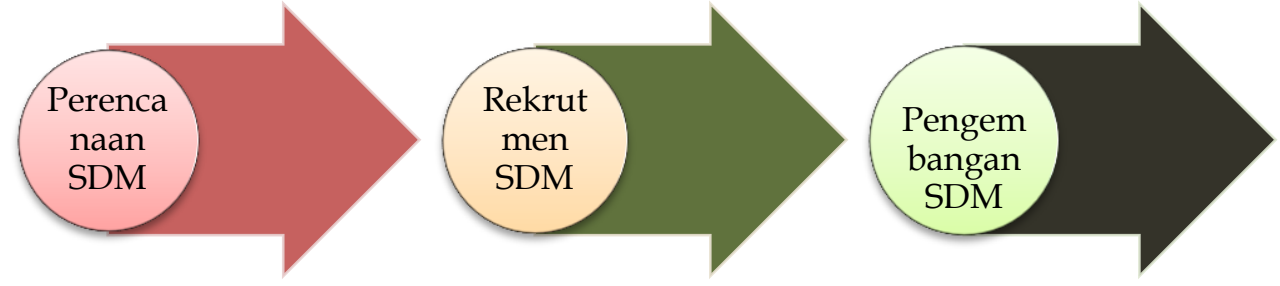

Gambar 2 : Tahapan pengembangan SDM di SMK Muhammadiyah Prambanan 
Pengembangan SDM di SMK Muhammadiyah Prambanan sesuai dengan gambar 2 dapat dijelaskan sebagai berikut;

\section{Perencanaan Sumber Daya Manusia}

SMK Muhammadiyah Prambanan banyak mengalami perkembangan dan pembaharuan ke arah peningkatan kualitas yang lebih baik. Salah satu konsep yang diterapkan oleh Riyanto (2019) selaku kepala sekolah SMK Muhammadiyah Prambanan adalah; menerapkan konsep total quality management dalam melakukan perencanaan sumberdaya manusianya.

Perencanaan sumber daya manusia dimulai melalui penilaian terhadap ketersediaan sumber daya manusia yang ada di SMK Muhammadiyah Prambanan secara menyeluruh, yang dilakukan pada rapat pimpinan secara khusus, mulai dari jumlah SDM yang ada, kompetensi yang dimiliki, kualifikasi pendidikannya, skill, kinerja dan lain sebagainya. Evaluasi ini dilakukan untuk memahami tantangan dari sisi SDM di lembaga, serta kompetensi, skill, kinerja yang harus dimiliki oleh SDM yang ada.

Hardika (2019) selaku Kabid SDM SMK Muhammadiyah Prambanan, mengungkapkan bahwa; SMK Muhammadiyah melakukan perencanaan yang di dalamnya termasuk analisis kebutuhan terhadap pendidik dan tenaga kependidikan yang memiliki kualifikasi, spesifikasi tertentu yang dibutuhkan oleh lembaga. Hal ini perlu dilakukan sebagai upaya untuk mengetahui kekuatan dan kelemahan SDM yang dimiliki sekolah, kebutuhan apa yang dibutuhkan oleh sekolah, serta menganalisa apa kurangnya sehingga dapat dilakukan perbaikan.

Adapun cara yang dilakukan untuk mengetahui apa kebutuhan sekolah, maka seluruh SDM yang dimiliki sekolah melakukan rapat secara khusus dengan pihak yayasan untuk membicarakan program yang telah dirancang dan yang telah dilaksanakan, sehingga dapat diketahui kinerja sumber daya yang dimilikinya. Dengan demikian, dapat diketahui program yang telah dilaksanakan dan program yang memiliki kendala. Melalui hal tersebut, sekolah dapat menentukan alternatif serta langkah startegis yang dapat digunakan untuk mencapai tujuan sekolah yang diharapkan.

Selanjutnya, Riyanto (2019) menuturkan bahwa; Perencanaan SDM di SMK Muhammadiyah Prambanan berfokus pada analisis terhadap kebutuhan tenaga pendidik dan kependidikan untuk masa yang akan datang, seperti promosi jabatan, mutasi pimpinan dan karyawan, pengurangan SDM, lowongan yang akan dibuka, dan lain sebagainya, sehingga akan diketahui forecast sumberdaya manusia.

Berangkat dari hal tersebut di atas, dapat diketahui bahwa perencanaan SDM di SDM SMK Muhammadiyah Prambanan dilakukan sebagai berikut;

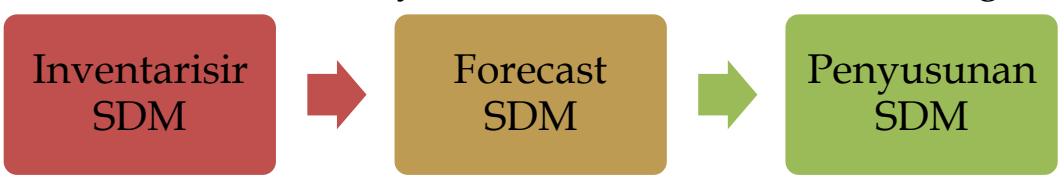

Gambar 3 : Perencanaan SDM di SMK Muhammadiyah Prambanan 
Gambar 3 tersebut menunjukkan bahwa; kegiatan perencanaan sumber daya manusia dilakukan secara terencana dan sistematis untuk mendapatk SDM yang unggul dan berkualitas, sehingga mampu meningkatkan dan mempertahankan keunggulan kompetitif di SMK Muhammadiyah Prambanan. Melalui perencanaan ini, pihak lembaga mampu memperoleh dan menemukan orang yang tepat untuk melakukan tugas-tugas yang dibutuhkan oleh sekolah sesuai dengan kompetensi dan keahliannya.

\section{Rekrutmen Sumber Daya Manusia}

Rekrutmen yang dilakukan oleh SMK Muhammadiyah Prambanan ditujukan untuk mencari dan menarik pelamar yang memiliki kompetensi dan skill untuk diseleksi menjadi tenaga pendidik dan tenaga kependidikan sesuai dengan posisi yang dibutuhkan.

Proses rekrutmen SDM di SMK Muhammadiyah Prambanan menurut Hardika (2019) dilakukan untuk menjaring dan menyeleksi para guru dan karyawan yang dibutuhkan, guna mengisi pada posisi tertentu sesuai dengan hasil keputusan rapat yang dilakukan bersama dengan yayasan. Pengisian pada posisi tertentu tersebut, tentunya berdasarkan pada hasil perencanaan sumber daya manusia yang sangat matang, yang dilakukan pada level pengambil kebijakan.

Menurut Riyanto (2019), langkah yang ditempuh SMK Muhammadiyah Prambanan dalam proses rekrutmen pendidik dan tenaga kependidikan, pihak sekolah terlebih dahulu membentuk kepanitiaan rekrutmen sumber daya manusia yang dibutuhkan, mulai dari penyampai informasi, penerima pendaftaran, sampai pada tim seleksi. Selanjutnya tim akan bekerja sesuai dengan tupoksi masing-masing, guna menjaring calon pegawai baru yang akan mengisi ruang yang kosong. Teknik seleksinya biasanya dilakukan secara terbuka dan materi seleksinya meliputi test tulis dan test lisan (interview).

Kegiatan rekrutman biasanya dimulai dengan mencari calon pelamar dan berakhir dengan diserahkannya surat lamaran kerja oleh para pelamar kepada tim seleksi. Setelah Rekrutmen, proses selanjutnya adalah proses penyeleksian pelamar, hingga terpilihnya pelamar kerja tersebut menjadi pegawai, guna mengisi posisi yang dibutuhkan di SMK Muhammadiyah Prambanan.

Pelamar yang diterima di SMK Muhammadiyah Prambanan adalah mereka yang memenuhi standar kriteria yang dibutuhkan. Hal yang membedakan SMK Muhammadiyah Prambanan dengan SMK lainnya dalam teknis perekrutan Pendidik dan Tenaga Kependidikan adalah; Pendidik dan tenaga kependidikan yang dinyatakan lolos/diterima oleh SMK Muhammadiyah Prambanan, terlebih dahulu akan diikutsertakan dalam program diklat. Selain diikutsertakan dalam diklat, guru yang baru diterima akan melaksanakan masa uji coba (training) selama 1 bulan, sebelum diputuskan sebagai tenaga pendidik dan kependidikan tetap di SMK Muhammadiyah Prambanan. 
Hal ini dilakukan untuk mendapatkan kualitas tenaga pendidik dan kependidikan yang unggul dan mapan. Melalui program diklat tersebut, pegawai baru akan mendapatkan materi dari para instruktur tentang beberapa hal, sehingga mereka bisa beradaptasi dengan budaya organisasi di SMK Muhammadiyah Prambanan dan terus mengasah serta meningaktkan kompetensi dan skillnya, sesuai dengan harapan dari lembaga.

\section{Pengembangan Sumber Daya Manusia}

Untuk meningkatkan kualitas Pendidik dan Tenaga Kependidikan (PTK) yang bergabung dengan SMK Muhammadiyah Prambanan, mereka diikutsertakan dalam kegiatan pelatihan, workshop dan sebagainya secara berkala, yaitu dua bulan sekali, yang tujuannya adalah untuk meningkatkan kemampuan dan keterampilan yang mereka miliki. Pihak sekolah mengirim beberapa orang PTK untuk mengikuti program pelatihan, sehingga ada tindak lanjut dari pelatihan yang diikutinya dan mampu membimbing PTK yang lain (tutor sebaya), yang belum diikutkan dalam pelatihan (Hardika, 2019).

Lebih lanjut, Hartati (2019) selaku Devisi Penjamin Mutu Pendidikan SMK Muhammadiyah Prambanan menjelaskan; dalam pengembangan sumber daya manusia, pihak sekolah juga memberikan kesempatan kepada para pendidik dan tenaga kependidikan untuk melanjutkan studi ke tahap selanjutnya yang lebih tinggi, agar dapat meningkatkan keilmuan, kompetensi dan skill mereka masing-masing. Dalam hal ini, Riyanto (2019) juga memberikan dukungan dan dorongan untuk hal tersebut, melalui pemberian motivasi yang dilakukan pada setiap kegiatan meeting sekolah.

Berdasarkan hal tersebut di atas, SMK Muhammadiyah Prambanan melakukan perencanaan, rekrutmen, serta pengembangan sumber daya manusia berbasis pada total quality management, sehingga kualitas sumber daya manusianya unggul dan mampu memberikan yang terbaik bagi lembaganya. Konsep pengelolaan sumber daya manusia berbasis total quality management berfokus pada upaya peningkatan kualitas SDM, pemenuhan terhadap kebutuhan SDM yang diinginkan oleh pelanggan, baik pelanggan internal maupun eksternal dan perbaikan secara berkelanjutan terhadap SDM yang dimiliki, sehingga visi dan misi lembaga dapat tercapai secara optimal.

Pengembangan sumber daya manusia berbasis total quality management di SMK Muhammadiyah Prambanan dapat dijelaskan sebagai berikut;

\section{Tabel 2 : Pengembangan Sumber Daya Manusia berbasis TQM di SMK Muhammadiyah Prambanan}

\begin{tabular}{ll}
\hline UNSUR & \multicolumn{1}{c}{ KETERANGAN } \\
\hline Standar Setting (Input) & Perencanaan pengembangan SDM di SMK \\
& Muhammadiyah Prambanan, di dalamnya mencakup \\
& analisis kebutuhan terhadap pendidik dan tenaga \\
& kependidikan (proses inventarisasi), prediksi atau \\
& perkiraan SDM (forecast), dan penyusunan kebutuhan \\
& SDM serta penetapan standar bagi tenaga pendidik \\
& sesuai dengan bidang yang diampu. \\
\hline
\end{tabular}


Monitoring Performance Pengembangan sumber daya manusia di SMK (Proses)

Muhammadiyah Prambanan, yaitu:

a. Pelatihan, seminar, workshop dan sebagainya secara berkala yaitu dua bulan sekali.

b. Pemberian kesempatan kepada pendidik dan tenaga kependidikan untuk melanjutkan studi ke tahap selanjutnya yang lebih tinggi agar memiliki kompetensi dan skill sesuai dengan harapan

c. Menjalin kerjasama dengan institusi lembaga pendidikan tinggi untuk memperoleh SDM guru dan tenaga kependidikan lainnya.

Correcting for Deveting Pengembangan sumber daya manusia terhadap (Output) pendidik dan tenaga kependidikan yang dimiliki SMK Muhammadiyah Prambanan berada dalam kategori baik. Pendidik dan tenaga kependidikan yang ada sesuai dengan standar dan kualifikasi yang ditetapkan SMK Muhammadiyah Prambanan.

News Standar

(Outcome) a. Kepala sekolah sebagai nahkoda lembaga, mampu membaca keinginan dan kebutuhan anggotanya.

b. Sekolah mampu merespon kebutuhan pelanggan sebagai pengguna jasa pendidikan.

c. Memanfaatkan kemajuan teknologi untuk pengembangan sumber daya manusia yang dimiliki SMK Muhammadiyah Prambanan.

Berangkat dari tabel 2 tersebut, dapat diketahui bahwa; pengembangan sumber daya manusia yang dilakuakn merupakan bagian dari upaya dalam memaksimalkan daya saing lembaga. Hal tersebut dapat dilakukan perbaikan secara terus menerus untuk memperoleh nilai atau mutu yang optimal (Cahyo, 2017). Proses peningkatan mutu pendidikan akan efektif dan efisien, apabila diikuti oleh sumber daya manusia yang kompeten dengan loyalitas dan semangat kerja tinggi (Waiganjo, 2012), sehingga akan menghasilkan kinerja yang tinggi pula dan berujung pada kepuasan pelanggan.

Harta yang paling penting yang dimiliki organisasi adalah sumber daya manusia, sementara manajemen efektif menjadi kunci dalam keberhasilan organisasi (Budi, 2012). Sumber daya manusia adalah potensi menggunakan pikiran dan karya yang dimiliki untuk digunakan secara optimal demi keberhasilan individu atau organisasi setelah potensi tersebut dikembangkan (Notoatmodjo, 1992).

Penerapan total quality management memiliki pengaruh dalam pengembangan sumber daya manusia. Pengaruh tersebut berkaitan dengan peran karyawan atau SDM dalam menunjukkan kinerjanya melalui keuletan membangun kreativitas keikhlasan dalam menjalankan program, serta kemampuan untuk mengembangkan diri, keyakinan serta manfaat manajemen mutu terpadu. Selain itu, pemimpin berperan aktif, terbuka, tidak acuh, dekat dengan anggota organisasi dan memiliki kualitas kepemimpinan (Bustamante, 
2011); (Syadzili, 2019). Di sisi lain, seluruh personalia harus merasa sama-sama memiliki dan teribat dalam menjalankan sistem (Suseno, 2014).

Manajemen sumber daya manusia merupakan upaya upaya untuk merencanakan, mengembangkan, memotivasi, serta mengevaluasi keseluruhan sumber daya manusia yang diperlukan oleh sekolah dalam pencapaian tujuannya (Marlina, 2015). Hal ini mencakup dari mulai memilih siapa saja yang memiliki kualifikasi dan pantas untuk menempati posisi dalam suatu organisasi (the right man on the right place) seperti yang disyaratkan pada suatu lembaga pendidikan hingga bagaimana agar kualifikasi ini dapat dipertahankan bahkan ditingkatkan serta dikembangkan dari waktu ke waktu.

Sumber daya manusia tersebut merupakan gerakan human investment. Human invesment adalah upaya pendidikan jangka panjang untuk melahirkan sumber daya manusia (Almasri, 2016). Pengembangan sumber daya manusia bukan merupakan persoalan yang mudah karena membutuhkan pemikiran, langkah aksi yang sistematik, dan serius (Çalişkan, 2010). Selain itu, manajemen sumber daya manusia (SDM) diperlukan agar dapat mewujudkan kegiatan dalam lembaga pendidikan, yang didalamnya terdapat dalam RENSTRA (Rencana Strategi), RENOP (Rencana Operasional), dan program tahunan sekolah (Nuraeni, 2019).

Islam juga mendorong untuk melakukan pengembangan terhadap sumber daya manusia melalui pelatihan terhadap para pegawai dengan tujuan untuk mengembangkan kompetensi dan kemampuan sehinggga dapat menjalankan tanggung jawab pekerjaannya. SDM yang profesional adalah SDM yang kafa'ah (memiliki keahlian), amanah (terpercaya), dan himmatul amal (memiliki etos kerja tinggi). Oleh karena itu diperlukan pembinaan dan pengembangan yang bertumpu pada tiga aspek, yaitu (1) syahsiyyah islamiyah (kepribadian Islamnya), (2) skill atau kemampuan dan keterampilan, (3) kepemimpinan dan kerjasamanya dalam tim (Anwar, 2012).

Melalui hal tersebut, maka pemanfaatan sumber daya manusia pada lembaga pendidikan mampu meningkatkan kontribusi sumber daya manusia terhadap organisasi dalam rangka mencapai produktivitas lembaga pendidikan (Widiansyah, 2018). Di samping itu, pengelolaan sumber daya manusia yang tepat guna juga dapat mewujudkan tercapainya visi dan misi lembaga secara efektif dan efisien.

\section{KESIMPULAN}

Pengembangan sumber daya manusia berbasis total quality management, selalu memegang prinsip pada perbaikan terus menerus serta berorientasi kepada pelanggan. Karakteristik dari implementasi total quality management dalam pengembangan sumber daya manusia berfokus pada pelanggan, baik internal ataupun eksternal, memiliki komitmen jangka panjang, selalu mengadakan perbaikan, dan menyelenggarakan pendidikan dan pelatihan. SMK Muhammadiyah Prambanan telah menerapkan konsep total quality management dan tetap memegang prinsip untuk selalu melakukan perbaikan secara terus menerus dan meningkatkan kualitas serta produktivitas dalam merespon tuntutan pasar. 
Adapun strategi yang dilakukan oleh pihak sekolah, meliputi; perencanaan, perekrutan, serta pengembangan sumber daya manusia untuk mencapai mutu pendidikan yang optimal. Strategi tersebut dikembangkan dengan mengadopsi adat istiadat, budaya (berbasis kearifan lokal) masyarakat, sehingga tidak bertentangan dengan kondisi real masyarakat di sekitarnya.

\section{DAFTAR PUSTAKA}

Almasri, M. N. (2016). Manajemen Sumber Daya Manusia: Implementasi dalam Pendidikan Islam. Kutubkhanah: Jurnal Penelitian Sosial Keagamaan, 19(2), 133-151.

Anwar, H. I. (2012). Peningkatan Mutu Sumber Daya Manusia dalam Konteks Pengembangaan Keunggulan Industri Rotan Nasional. Jurnal Manajerial, 1(1), 7-10.

Aryana, I. N., Wardana, I. M., \& Yasa, N. N. K. (2017). Membangun Keunggulan Bersaing Melalui Kinerja Sistem Informasi dan Customer Intimacy dalam Meningkatkan Kinerja Pemasaran. E-Jurnal Ekonomi Dan Bisnis Universitas Udayana, 6(4), 1343-1364.

Budi, W Soetjipto, D. (2012). Paradigma Baru Manajemen Sumber Daya Manusia. Yogyakarta: Amara Book.

Buniarto, E. A. (2015). Penerapan Total Quality Management dalam Peningkatan Sumber Daya Manusia. Akademika, 13(2), 53-60.

Bustamante, R., \& Combs, J. P. (2011). Research Courses in Education Leadership Programs: Relevance in an Era of Accountability. International Journal of Education Policy \& Leadership, 6(3), 1-11.

Cahyo, A. N. (2017). Manajemen Sumber Daya Manusia (SDM) Pendidikan dalam Meningkatkan Daya Saing SDIT Ar-Rahmah Pacitan. Muslim Heritage, 1(2), 263-286.

Çalişkan, E. N. (2010). The Impact of Strategic Human Resource Management on Organizational Performance. Journal of Naval Science and Engineering, $6(2), 100-116$.

Hardika, B. S. (2019). Interview. Prambanan, Sleman, Yogyakarta.

Hartati. (2019). Interview. Prambanan, Sleman, Yogyakarta.

Hartatik, I. P. (2014). Buku Praktis Mengembangkan SDM. Yogyakarta: Laksana.

Hasan, M. T. (2003). Islam dan Manajemen Sumber Daya Manusia. Jakarta: Lantabora Press.

Hijrawan, R. (2019). Pengembangan Manajemen Sumber Daya Manusia berbasis TQM di Madrasah Aliyah Nurul Ummah Kota Gede Yogyakarta. Al-Fahim: Jurnal Manajemen Pendidikan Islam, 1(2), 109-134.

Jaya, E. (2017). Manajemen Sumber Daya Manusia Pendidikan SMART Ekselensia Indonesia. Jurnal Pendidikan Dompet Dhuafa, 7(2), 1-8.

Krismiyati, K. (2017). Pengembangan Sumber Daya Manusia dalam Meningkatkan Kualitas Pendidikan di SD Negeri Inpres Angkasa Biak. Jurnal Office, 3(1), 43-50.

Marlina, L. (2015). Manajemen Sumber Daya Manusia dalam Pendidikan. Istinbanth, 15(2), 123-139. 
Muhardi. (2004). Aspek-aspek Keunggulan Bersaing Perguruan Tinggi. Mimbar, 20(2), 179-193.

Notoatmodjo, S. (1992). Pengembangan Sumber Daya Manusia. Jakarta: Rineka Cipta.

Nuraeni. (2019). Manajemen Sumber Daya Manusia Lembaga Pendidikan. Jurnal Idaarah, 3(1), 124-137.

Priyatna, M. (2016). Manajemen Pengembangan SDM pada Lembaga Pendidikan Islam. Edukasi Islami: Jurnal Pendidikan Islam, 5(9), 1231-1250.

Rachmawati, I. K. (2008). Manajemen Sumber Daya Manusia. Yogyakarta: Andi.

Riyanto, I. (2019). Interview. Prambanan, Sleman, Yogyakarta.

Sugiyono. (2017). Metode Penelitian Kuantitatif, Kualitatif, dan RED. Bandung: Alfabeta.

Suhermanto, S., \& Anshari, A. (2018). Implementasi TQM terhadap Mutu Institusi dalam Lembaga Pendidikan. Al-Tanzim: Jurnal Manajemen Pendidikan Islam, 2(1), 107-113.

Supardi, E. (2006). Total Quality Managemet dalam Perberdayaan Sumber Daya Manusia. Jurnal Geografi GEA, 6(1), 1-11.

Suseno, A. Z. A. dan. (2014). Penerapan TQM dalam Meningkatkan Kinerja UMKM. Jurnal Studi Manajemen, 8(2), 112-117.

Syadzili, M. F. R. (2019). Polarisasi Tahapan Kepemimpinan Transformatif Pendidikan Islam. Al-Tanzim: Jurnal Manajemen Pendidikan Islam, 3(1), 5581.

Syam, A. R. (2017). Konsep Kepemimpinan Bermutu dalam Pendidikan Islam. Al-Ta'dib, 12(2), 49-69.

Waiganjo, M., Mukulu, E., \& Kahiri, J. (2012). Relationship between Strategic Human Resource Management and Firm Performance of Kenya's Corporate Organizations. International Journal of Humanities and Social Sciences, 2(10), 62-70.

Walidin, W. (2016). Arah Pengembangan Sumber Daya Manusia dalam Dimensi Pendidikan Islam. Jurnal Edukasi, 2(2), 148-163.

Warisno, A. (2018). Pengembangan Sumber Daya Manusia dalam Peningkatan Mutu Lulusan pada Lembaga Pendidikan Islam di Kabupaten Lampung Selatan. Ri'ayah, 3(2), 99-113.

Widiansyah, A. (2018). Peranan Sumber Daya Pendidikan sebagai Faktor Penentu dalam Manajemen Sistem Pendidikan. Cakrawala, 18(2), 299-234. 